\title{
Minimal Extension for Maximal Results - Review on Minimal Intervention Paediatric Dentistry
}

\section{Voleti Sri Srujana Aravinda ${ }^{1 *}$, Chaitanya Ram Kandregula ${ }^{2}$, Malathi $Y^{3}$, Madhavi Krishna $\mathbf{M}^{2}$, Nikitha BS ${ }^{3}$ and B Malathi Sree ${ }^{4}$}

${ }^{1}$ Postgraduate, Anil Neerukonda Institute of Dental Sciences, Visakhapatnam, Andhra Pradesh, India

${ }^{2}$ Associate Professor, Anil Neerukonda Institute of Dental Sciences, Visakhapatnam, Andhra Pradesh, India

${ }^{3}$ Assistant Professor, Anil Neerukonda Institute of Dental Sciences, Visakhapatnam, Andhra Pradesh, India

${ }^{4}$ Post Graduate, Anil Neerukonda Institute of Dental Sciences, Visakhapatnam, Andhra Pradesh, India

*Corresponding Author: Voleti Sri Srujana Aravinda, Postgraduate, Anil Neerukonda Institute of Dental Sciences, Visakhapatnam, Andhra Pradesh, India.
Received: November 26, 2021

Published: December 30, 2021

(C) All rights are reserved by Voleti Sri

Srujana Aravinda., et al.

\section{Abstract}

Background: Recent advances in dentistry have transformed approach to the diagnosis and management of dental caries. This article review's the scientific basis for early diagnosis of dental caries, remineralization of tooth structure and reduction of cariogenic bacteria by using minimally invasive techniques.

Methodology: Literature survey was carried out in electronic databases such as PubMed, COCHRANRE library, SCOPUS, Science Direct, EMBASE, using key words such as "Minimally Invasive Dentistry, recent advances in paediatric dentistry, smart materials and techniques". The literature search revealed 562 articles of which 47 were selected after reading the full text articles.

Conclusions: Modern advancements have led to the development of minimally invasive paediatric dentistry. Though emerging technology will aid in shift to Minimal invasive dentistry but there are still technological, economic and knowledge barriers to their complete adoption into the paediatric dental practice.

Keywords: Advanced Diagnostic Aids; Minimal Invasive Dentistry; Recent Advances in Paediatric Dentistry

\section{Introduction}

Though the concept of MID has been stressed upon for a decade, uptake of this philosophy has not been at the global level. MID should be the standard of care in paediatric restorative dentistry, as it avoids extensive restorative interventions as well as supervised neglect. As the dental profession worldwide faces the challenges of dealing with high rates of dental caries in paediatric patients, it is even more important to incorporate these concepts into paediatric dental practice to deal with the challenge of preventive and therapeutic management of dental caries in children [1].

\section{Search criteria}

A survey was conducted to find out the available literature on the topic of minimal invasive dentistry. the MeSH terms used for searching were 'minimal invasive dentistry', minimal dentistry, ART, advances in paediatric dentistry, smart materials and regenerative dentistry. the search engine included was google in searching the medical and electronic databases. the electronic databases searches were the, PubMed, Scopus, science direct, web of science and Cochrane library. 
Articles published in between the years of 2000 to September 2021 were included in the literature survey.

\section{Selection criteria}

Qualitative assessment was done in selecting the articles which were available in the databases.

\section{Inclusion criteria}

- $\quad$ Studies on characteristics of minimal intervention dentistry

- $\quad$ Studies on recent advances in dentistry

- Investigation reports, clinical trials and randomized control trials

The literature search revealed 562 articles of which 89 articles were selected after reading the title and abstracts. After reading the full text articles 59 articles matching the inclusion criteria were selected for the review.

\section{Definition}

Minimum (or minimal) intervention dentistry (MI) can be defined as a philosophy of professional care concerned with the first occurrence, earliest detection, and earliest possible cure of disease on micro (molecular) levels, followed by minimally invasive and patient-friendly treatment to repair irreversible damage caused by such disease [1,2].

Principles of minimal intervention paediatric dentistry [MIPD] [3,4]:

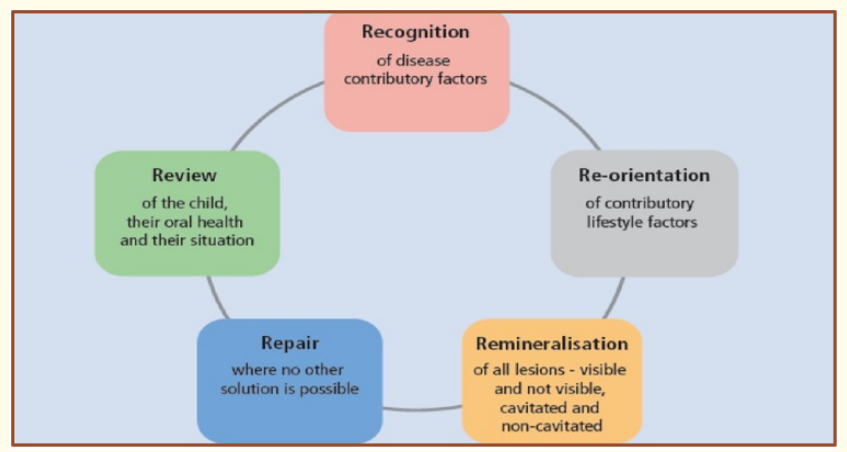

Figure 1: Principles of Minimal Intervention Paediatric Dentistry.
Recognition: Early identification and assessment of risk factors for dental caries

\section{Detection of caries [5]}

Evaluation of individual caries risk cannot be separated from the actual diagnosis of carious lesions. It is essential to assess the risk factors for the correct choice of preventive, interceptive, or therapeutic care.

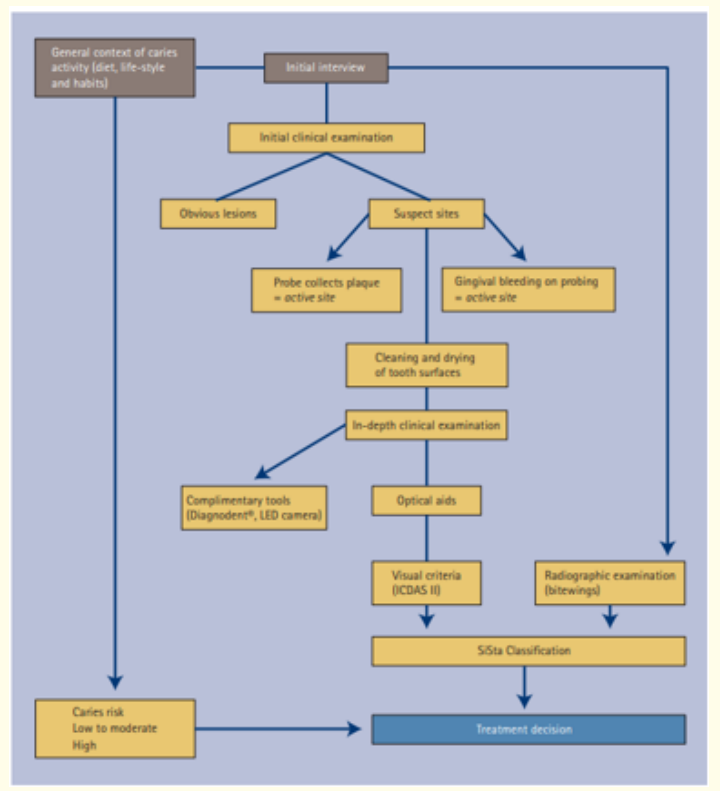

Figure 2: Flow-chart of assessment of initial carious lesions.

\section{Visual examination [6]}

- Visual examination is not an ideal method to diagnose dental caries as most of the lesions go undetected.

- $\quad$ Clinical accuracy of caries detection by visual examination is only $25-30 \%$.

Tactile examination with a probe [7]

- Use of explorer can cause irreversible damage to the tooth structure which can be remineralized,

\section{- $\quad$ Dr.Nigel B.Kidd: “SHARP EYES BUT BLUNT PROBE”.}

Another suggested method is assessment of the incidence of discontinuities in enamel or micro-cavitations evaluated through 
WHO/CPI/PSR probe which has a ball end with a sphere measuring $0.5 \mathrm{~mm}$ in the extremity [8].

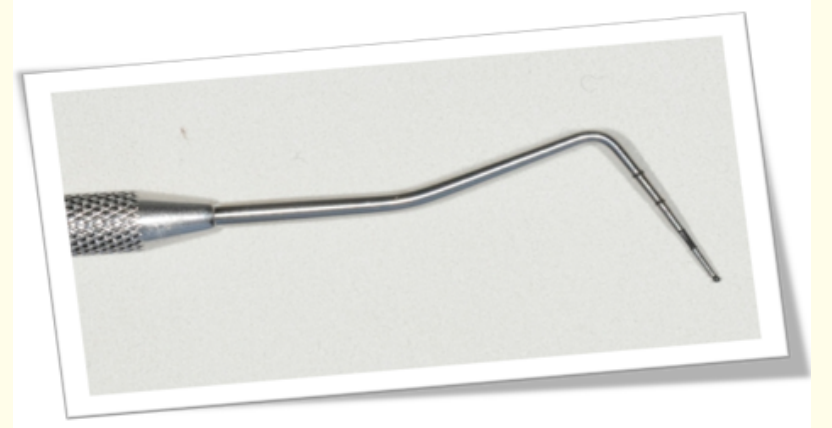

Figure 3: Probe with round tip.

\section{ICDAS system [9]}

Carious lesions are classified according to the site of occurrence in this system occlusal (site 1), proximal (site 2), and cervical (site 3 ), then further classified according to their stage.

\begin{tabular}{|c|c|c|c|c|}
\hline $\begin{array}{l}\text { ICDAS } \\
\text { Code }\end{array}$ & \begin{tabular}{|l|} 
Criteria for visual \\
lesion detection
\end{tabular} & $\begin{array}{l}\text { Degree of severity } \\
\text { of lesion }\end{array}$ & \begin{tabular}{|l|} 
SiSta" \\
stage
\end{tabular} & Therapeutic options \\
\hline \begin{tabular}{l|l}
0 \\
\end{tabular} & Sound surface & & & Not necessary \\
\hline 1 & $\begin{array}{l}\text { Earliest optical change, } \\
\text { visible on drying enamel }\end{array}$ & $\begin{array}{l}\text { Demineralisation in outer } \\
\text { third of enamel }\end{array}$ & \multirow[b]{2}{*}{0} & \multirow{2}{*}{$\begin{array}{l}\text { Minimal intervention; } \\
\text { non-invasive care, } \\
\text { remineralisation or sealant }\end{array}$} \\
\hline 2 & $\begin{array}{l}\text { Clear enamel change; white } \\
\text { or brown blemishes, visible } \\
\text { without drying }\end{array}$ & $\begin{array}{l}\text { Demineralisation reaching } \\
\text { the inner third of enamel, } \\
\text { possibly the ADJ }\end{array}$ & & \\
\hline 3 & Localised break in enamel & $\begin{array}{l}\text { Demineralisation of outer } \\
\text { third of dentine }\end{array}$ & \multirow[b]{2}{*}{1 and 2} & \multirow[b]{2}{*}{$\begin{array}{l}\text { Minimal intervention; } \\
\text { adhesive ultra conservative } \\
\text { restoration }\end{array}$} \\
\hline 4 & Dentine not visible & $\begin{array}{l}\text { Demineralisation of } \\
\text { middle third of dentine, } \\
\text { no weakening of dental } \\
\text { crown structure }\end{array}$ & & \\
\hline 5 & $\begin{array}{l}\text { Enamel opaque or greyish, } \\
\text { suggestive of an underlying } \\
\text { dentine lesion, with or } \\
\text { without enamel cavitation }\end{array}$ & $\begin{array}{l}\text { Demineralisation of middle } \\
\text { third of dentine, weakening } \\
\text { of dental crown structure }\end{array}$ & \multirow[b]{2}{*}{3 and 4} & \multirow{2}{*}{$\begin{array}{l}\text { Operative dental care; } \\
\text { functional crown } \\
\text { restoration with or } \\
\text { without cusp coverage }\end{array}$} \\
\hline 6 & Dentine cavity & $\begin{array}{l}\text { Demineralisation of inner } \\
\text { third of dentine, } \\
\text { undermining of cusp } \\
\text { structure and support }\end{array}$ & & \\
\hline
\end{tabular}

Figure 4: Criteria for visual detection of carious lesions [ICDAS] and SiSta classification.

\section{Contribution of magnification to minimize intervention [10]}

Improved visualization of the operator potentially reduces the number of operative treatments. At higher magnification, signs of inactive lesion like dark colour, no retention of dental plaque, shininess encourage postponement of such operative treatment.

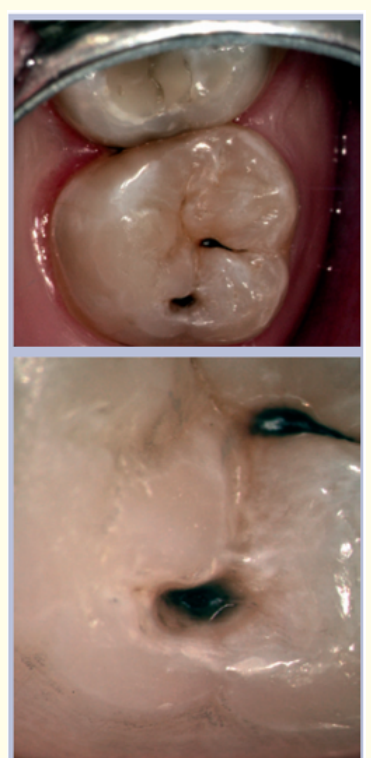

Figure 5: Normal view and magnified view of dental caries.

\section{Caries risk assessment [11]}

Caries Risk: The probability that a specific number of new lesions will develop and/or specific number of existing lesions will progress over a specified period of time.

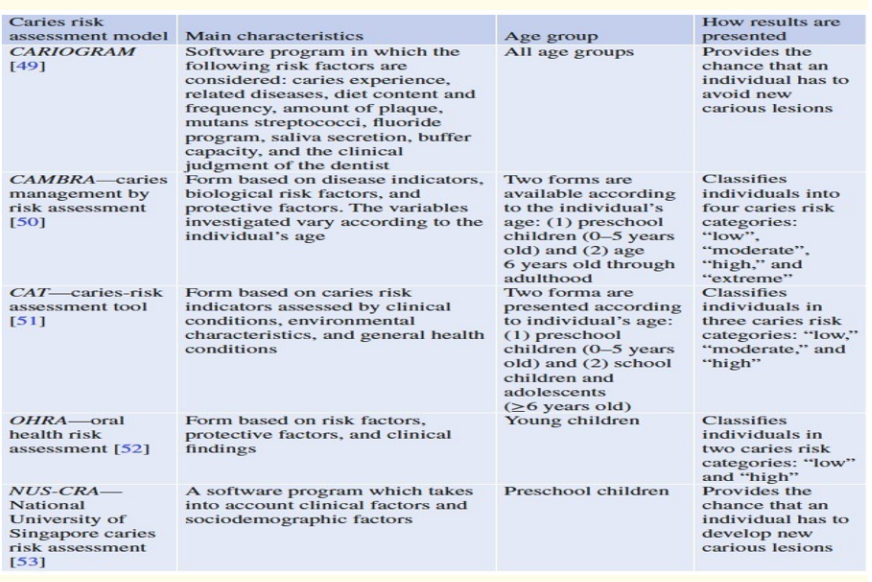

Figure 6: Caries Risk Assessment.

\section{Diagnostic aids [12]}

- Illumination methods: 
- $\quad$ Fiber-optic transillumination (FOTI)

- Wavelength dependent FOTI

- $\quad$ Digital imaging FOTI (DIFOTI).

- $\quad$ Midwest caries

- Endoscopy:

- Endoscopically viewed filtered fluorescence

- White light fluorescence

- Videoscope

- Intraoral television camera (IOTV)

- Electrical conductance measurement (ECM)

- $\quad$ Radiography

- Digital imaging radiography

- $\quad$ Subtraction radiography

- $\quad$ Computed tomography (CT)

- X-ray microtomography

- Polarization sensitive optical coherence tomography

- $\quad$ Transverse microradiography (TMR)

- $\quad$ Tuned aperture CT (TACT)

- $\quad$ Lasers

- $\quad$ Quantitative light-induced fluorescence (QLF)

- Diagnodent

- $\quad$ Species specific monoclonal antibodies

- Cariescan

Identification of oral micro flora

Caries activity tests $[13,14]$

Caries activity tests rely on the notion of a specific odontogenic infection.

Specific bacterial predominance is attributed to its acidogenic and aciduric nature after a selective growth benefit over the other non-acid tolerant organisms. Identification of caries susceptible children through basic diagnosis techniques is not feasible, thus, caries activity tests have been evolved to avert this difficulty.
Reduction and re-orientation: To eliminate or minimize risk factors of dental caries

Elimination of risk factors [15]:

Non-invasive interventions deal with prevention of dental caries and maximum conservation of demineralized but non-cavitated enamel and dentin. It is possible by eliminating bacteria and their by-products and by aiding remineralization process i.e., fluorides

- Oral health education

- Fluoride in prevention of dental caries

- Professionally applied topical fluorides

- Self-applied topical fluorides

- Fluoride mouth rinses

- Fluoride dentifrices.

Chemical plaque control agents

- $\quad$ Enzymes

- Antibiotics

- $\quad$ Bisbiguanide antiseptics

- Quatenary ammonium compounds

- Detergents

- $\quad$ Oxygenating agents

- Chlorhexidine

- $\quad$ Acidified sodium chlorite

- Preventive/prophylactic Measures like Chewable tooth brush.

This disposable tooth brush comprised of xylitol, flavouring agent, aqua, and polydextrose. Not recommended below age of 6 years [16].

Modern methods for caries control [17]:

- Bacterial transplantation or replacement in the oral cavity

- Ozone disinfection

- $\quad$ Phyto therapeutic agents 


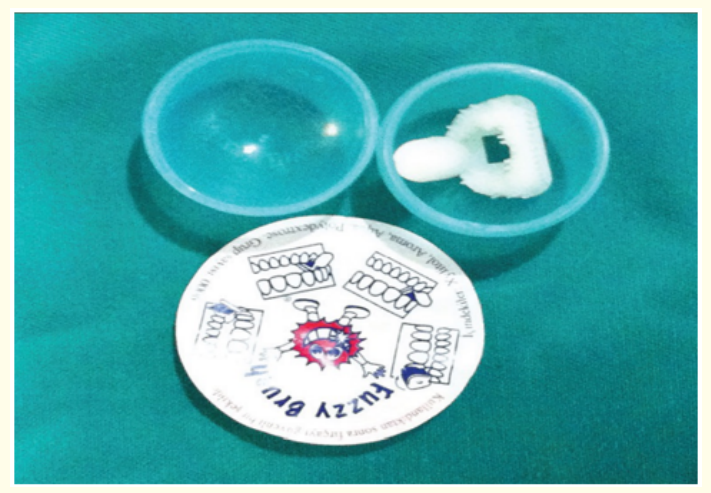

Figure 7: Chewable tooth brush- Fuzzy brush.

- Antimicrobials encapsulated in controlled-release microcapsules

- $\quad$ Sustained-release materials and smart materials

- New biomaterials that buffer $\mathrm{pH}$ and that have impervious margins

- Combination therapy (propolis/fluoride/mineral concentrates).

Ecological approaches for caries prevention [18]:

- Antimicrobial Peptides - Natural (lactoferrin, cathelicidins, histatins, defensins),

- $\quad$ Specifically (or Selectively) Targeted Antimicrobial Peptides [19].

\begin{tabular}{|c|c|}
\hline STAMPS & Organisms inhibited \\
\hline C16G2 & S. mutans \\
\hline SM6(L1) B33 & S. mutans \\
\hline SM7 & s. mutans \\
\hline $2 \mathrm{~A} 4,2 \mathrm{~B} 1,2 \mathrm{~B} 5,2 \mathrm{~B} 7,3 \mathrm{H} 5,4 \mathrm{B9}$ & s. mutans \\
\hline LL-37 & $\begin{array}{l}\text { S. mutans, Lactobacillus, } \\
\text { Actinomyces viscosus, Actinobacillus } \\
\text { actinomycetemcomitans }\end{array}$ \\
\hline K4-S4 (1-15a) & $\begin{array}{l}\text { Fusobacterium nucleatum, enteric } \\
\text { Escherichiacoli, s. mutans, } \\
\text { Lactobacillus, Actinomyces viscosus. }\end{array}$ \\
\hline dhvar4a & $\begin{array}{l}\text { Fusobacterium nucleatum, enteric } \\
\text { Escherichia coli, } s \text {. mutans, } \\
\text { Lactobacillus, Actinomyces viscosus, } \\
\text { Actinobacillus actinomycetemcomitans }\end{array}$ \\
\hline
\end{tabular}

Figure 8: List of few currently developed peptides against oral infections.

- $\quad$ Probiotics: "Substrate that is selectively utilized by host Microorganisms conferring A health benefit" [Gibson., et al. 2017]
- Prebiotics: These are animate microorganisms which are administered in Adequate amounts to confer a health benefit on the host" [Sanders, 2008]

- Sugar Polyols

- Quorum-Sensing Targets

- Natural Products

- $\quad$ Replacement Therapy with "Designer" Bacteria

- $\quad$ Recent Approaches - Compounds affecting bacterial virulence proteins i.e., Calcium phosphate-Osteopontin particle, Nanoparticles Graphene oxide.

Regeneration: To arrest and converse incipient lesion

Since the 1980s, it has been an established belief that fluoride action is predominantly through its topical but not systemic as previously thought.

The proposed four mechanisms of fluoride are [20]:

- Inhibits demineralization

- Enhances remineralization

- Inhibit essential bacterial activity.

- The long-term benefit is through intraoral reservoirs which are formed after fluoride application through toothpaste, varnish or restorative material and is then released into the saliva overtime.

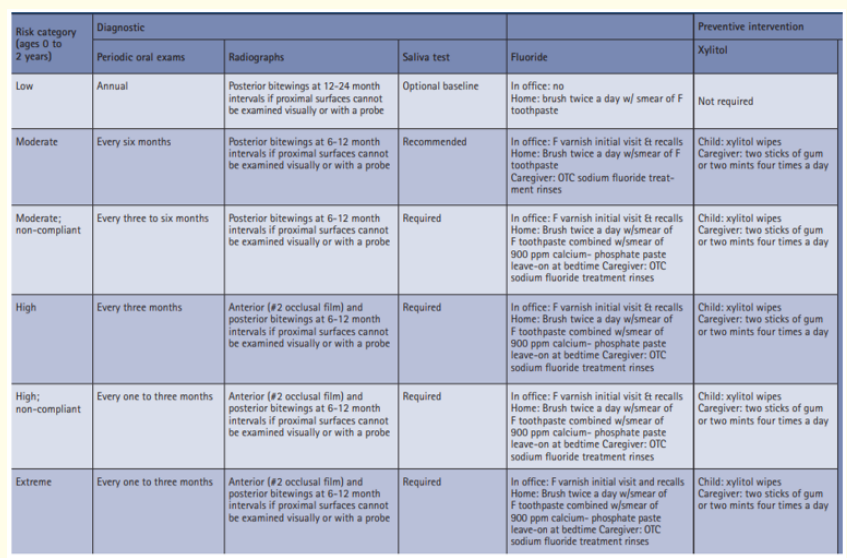

Figure 9: Caries management protocol for 0-2 years old. 


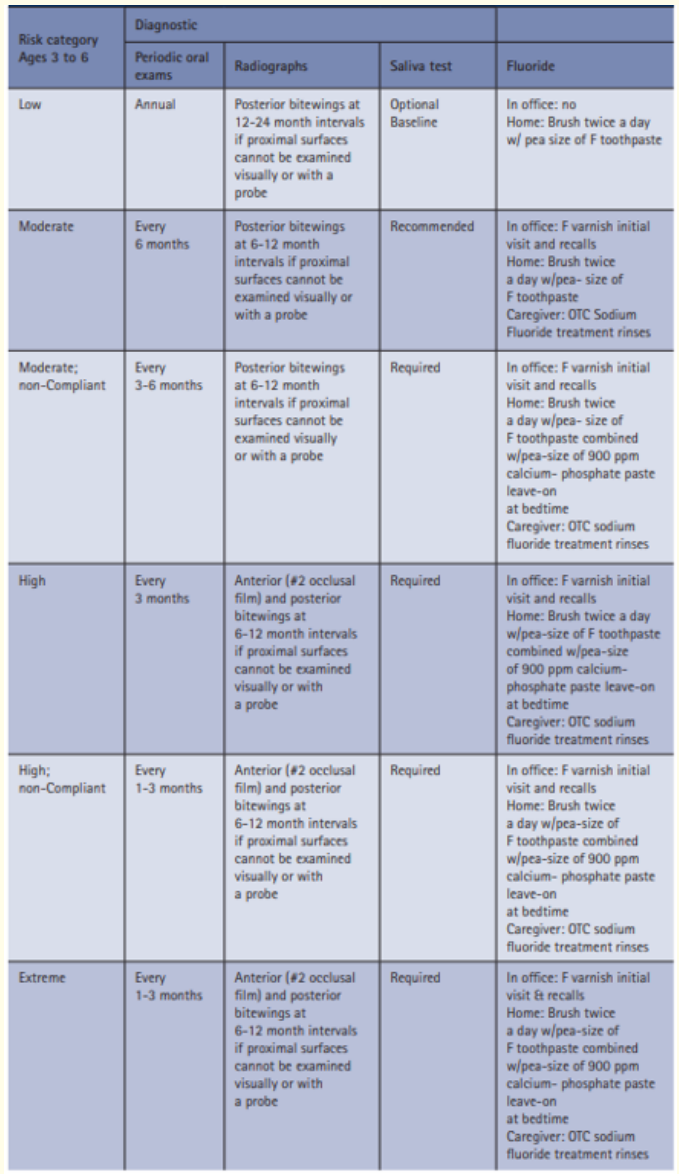

Figure 10: Caries management protocol for 3-6 years old.

\section{Fluoride [21]:}

- $\quad$ Silver Diamine Fluoride - SDF-

- $\quad$ Silver Nitrate + Fluoride - SNF

- $\quad$ Nano Silver Fluoride - NSF.

\section{Silver diamine fluoride [22]}

Silver diamine fluoride 38\% (Advantage Arrest, Elevate Oral Care) has been shown to be effective for on-label uses (treatment of dentinal hypersensitivity), as well as some off-label uses (arresting caries in children and adults, and caries diagnosis).

Mechanism includes Occlusion of dentinal tubules, anti-bacterial action, prevention of collagen and mineral degradation.
Need for shift to non- fluoride strategies [23]:

- $\quad$ Fluoride's limited effect on pit and fissure caries.

- $\quad$ Potential adverse effects (e.g., fluorosis) due to overexposure to fluoride

- $\quad$ Fluoride toxicity.

- Not a capable alternate in active disease process.

- Certain countries do not have fluoridated products.

The above disadvantages demand the need for non-fluoride remineralizing agents.

Non-fluoride remineralizing agents [23]:

\begin{tabular}{|c|c|}
\hline Technology & Commercial Product \\
\hline Biomimetic systems & $\begin{array}{c}\text { Curodont Repair / Curodont Protect } \\
\text { Apagard toothpaste / Desensin oral } \\
\text { rinse }\end{array}$ \\
\hline \multicolumn{2}{|l|}{$\begin{array}{l}\text { Agents that deliver calcium and phosphate } \\
\text { ions to tooth surface }\end{array}$} \\
\hline $\begin{array}{l}\text { 1. Casein phosphopeptide stabilised calcium } \\
\text { phosphate (rcaldentT, CPP-ACP) }\end{array}$ & $\begin{array}{l}\text { Tooth mousse / MI paste cremes, } \\
\text { Trident white sugar-free gum, MI } \\
\text { paste ONE toothpaste }\end{array}$ \\
\hline $\begin{array}{l}\text { 2. Unstabilised amorphous calcium phosphate } \\
\text { (ACP, enamelon TM) }\end{array}$ & $\begin{array}{l}\text { Enamelon toothpaste, Enamel Pro } \\
\text { varnish }\end{array}$ \\
\hline $\begin{array}{l}\text { 3. Bioactive glass containing calcium sodium } \\
\text { phosphosilcate (Nova Min TM) }\end{array}$ & NovaMin toothpaste \\
\hline 4. Functionalised $\beta$-tricalcium phosphate & $\begin{array}{l}\text { Clinpro toothpaste, Clinpro white } \\
\text { varnish }\end{array}$ \\
\hline $\begin{array}{l}\text { Agents that modify the biofilm } \\
\text { 1. Arginine bicarbonate and urea }\end{array}$ & Colgate - Palmolive ( $1.5 \%$ arginine) \\
\hline 2.0zone gas & HealOzone, OZOTOP \\
\hline \multicolumn{2}{|l|}{ Agents that neutralise organic acids } \\
\hline \multirow{2}{*}{\multicolumn{2}{|c|}{ 1. Calcium glycerophosphate }} \\
\hline 2. Calcium phytate & \\
\hline \multicolumn{2}{|l|}{ 3. Calcium lactate } \\
\hline \multicolumn{2}{|l|}{ Anti-plaque agents } \\
\hline $\begin{array}{l}\text { 1. Antimicrobials and antibiotics chlorhexidine } \\
\text { triclosan }\end{array}$ & Listerine \\
\hline 2. Xylitol & $\begin{array}{c}\text { Xylitol chewing gums, Xylitol gummy } \\
\text { bear snacks, Xylitol syrups, Xylitol } \\
\text { toothpaste, Xylitol mouth rinse }\end{array}$ \\
\hline 3. Metallic salts & \\
\hline
\end{tabular}

Figure 11: Non fluoride enamel remineralizing technologies.

\section{Repair versus replacement}

- $\quad$ Repair is indicated mainly in the occasion of results which are clinically unsatisfactory and no longer adequate. Repair is a minimally invasive approach i.e., addition of restorative material to an existing restoration.

- $\quad$ Replacement, if indicated, is for a more severe problems where intervention is necessary, and a repair is not possible; it is the removal of the restoration in- toto [24]. 
Non - cutting strategies

Atraumatic restorative treatment [25]:

The Atraumatic Restorative Treatment (ART) is a non - invasive procedure based on removing carious tooth tissues using hand instruments and restoring it with a glass ionomer cement.

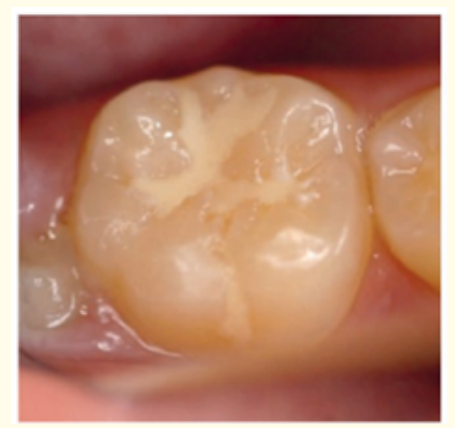

Figure 12: Atraumatic restorative treatment.

\section{Halls technique [26]:}

The Hall technique is a recent method of biological sealing for carious lesions in primary molars. The rationale being creation of a non- nutritive environment for bacteria by sealing them from oral environment. Recent literature suggest that Hall technique is measured and a promising restorative option with high acceptability and longevity; with low failure rate for managing carious primary molars. However, it should be chosen in restricted cases.

\section{Chemomechanical caries removal [27]:}

Chemo mechanical caries removal (CMCR) is another non-invasive technique, eradicating infected dentine through principal of dissolution via a chemical agent. The advantages of being the inconvenience of using burs and local anaesthesia is evaded, thus causing less discomfort and even conserving healthy dental structure.

\section{Conservative operative management strategies}

The international caries consensus collaboration (ICCC) recommendations on carious tissue removal [28]:

- Nonselective removal to hard dentine (formerly complete excavation or complete caries removal).

- $\quad$ Selective removal to soft dentine is recommended in deep cavitated lesions.
- $\quad$ Stepwise removal of carious tissue removal in two stages.

- A last strategy is not removing any carious tissue at all.

Lately, conservative forms of operative intervention have been endorsed that concentrate on the removal of carious dentin thus preserving maximal sound tooth structure.

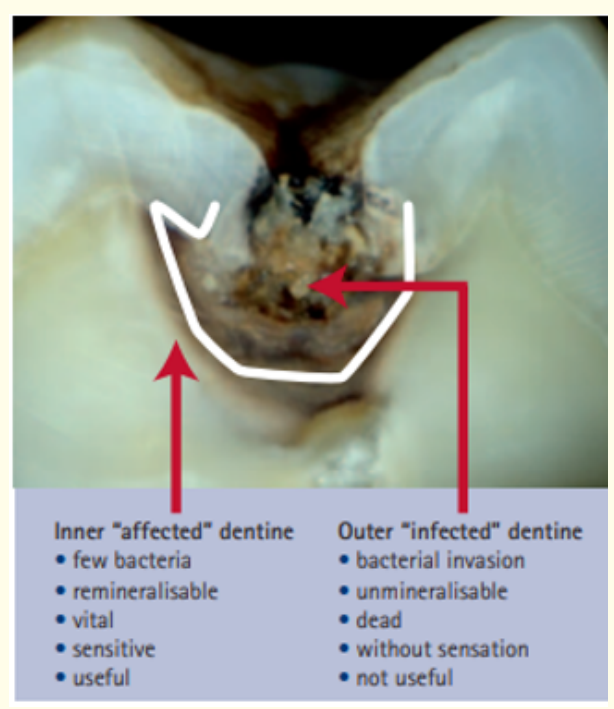

Figure 13: Affected dentin Vs Infected dentin.

Layers of a dentine caries lesion. The 'outer carious dentine' or 'infected dentine' is soft and infected and should be removed. The 'inner carious dentine' or 'affected dentine' can remineralise and should be retained. Smart prep burs can be used to selectively remove infected dentin [32].

Tooth cutting strategies [29]:

There are several clinical technologies available for cutting teeth and removing caries.

Modifications in the burs [30]:

Fissurotomy bur: three types:

- $\quad$ Original fissurotomy

- $\quad$ Micro STF and

- $\quad$ Fissurotomy Micro NTF

- Micro Diamond Prep System (Brasseler USA): set of eight burs. 


\begin{tabular}{|l|l|l|}
\hline Mechanism & Dental substrate affected & Tooth-cutting technology \\
\hline Mechanical, rotary & $\begin{array}{l}\text { Sound or carious enamel } \\
\text { and dentine }\end{array}$ & SS, CS, diamond, TC and plastic burs" \\
\hline $\begin{array}{l}\text { Mechanical, } \\
\text { non-rotary }\end{array}$ & $\begin{array}{l}\text { Sound or carious enamel } \\
\text { and dentine }\end{array}$ & $\begin{array}{l}\text { Hand instruments (excavators, chisels), air-abrasion, } \\
\text { air-polishing"; }\end{array}$ \\
\hline Chemomechasonics, sono-abrasion
\end{tabular}

Figure 14: Overview of different tooth cutting strategies.

- $\quad$ Polymer Caries Removal Burs (SMART BURS): Slow speed rotary handpiece at 500-800 $\mathrm{rmp}$.

- $\quad$ Ceramic burs: The CeraBurs are all- ceramic round burs made of alumina-yttria stabilized zirconia. They are available in different diameter sizes.

Designs of cavity preparations [31]:

A systematic review of clinical studies pertaining to three specific conservative operative techniques was published in 2001, including a review of proximal-only, "tunnel," and preventive resin restorations (PRRs).

- Tunnel preparations/Open/Close/Partial/Blind

- Saucer preparations

- Box only preparations

- Slot or Minibox cavity Preparations

- Microchip cavity preparation

- Full box cavity preparation.

Modified cavity preparations [32]:

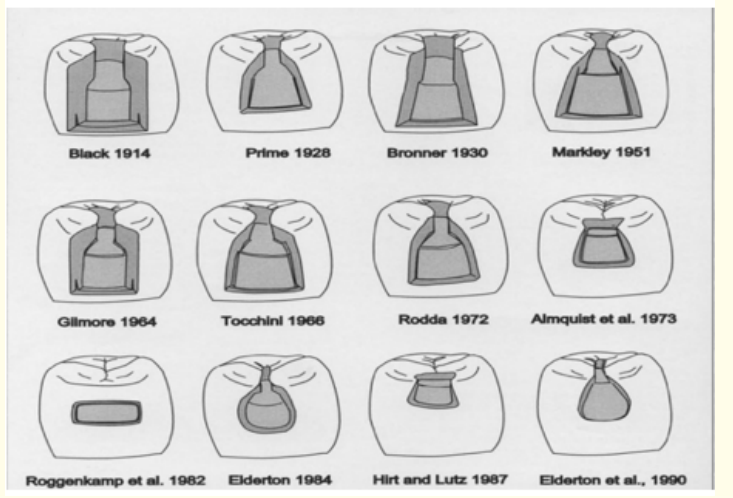

Figure 15: Modified cavity preparations.

\section{Sonic abrasion [33]:}

Sono-abrasion is a technique of selective preparation of enamel and dentine offering excellent efficacy and safety. This technology is alternative to rotary instrumentation. It is compatible with direct and indirect adhesive restoration techniques.

\begin{tabular}{|l|l|}
\hline Type of tip & Use \\
\hline $\begin{array}{l}1 \text { entirely abrasive tip: } \\
\text { pointed cone shape }\end{array}$ & $\begin{array}{l}\text { Prevention (sealant) } \\
\text { Opening and preparation of fissures }\end{array}$ \\
\hline 1 entirely abrasive tip: \\
round with collar shape & $\begin{array}{l}\text { Occlusal mini-cavities, } \\
\text { Access to dentinal lesions }\end{array}$ \\
\hline 2 MD 2-surface tips: & $\begin{array}{l}\text { Preparation of approximal mini-cavities } \\
\text { Finishing cavity margins } \\
\text { Selective superficial abrasion }\end{array}$ \\
\hline 2 MD 2-surface tips: & $\begin{array}{l}\text { Preparation of approximal boxes } \\
\text { Direct restorations and inlays, onlays }\end{array}$ \\
\hline approximal box shape & $\begin{array}{l}\text { Interproximal clearing } \\
\text { Preparation of approximal margins } \\
\text { Preparation of veneers }\end{array}$ \\
\hline 2 MD 2-surface tips: & $\begin{array}{l}\text { Access and interproximal clearing } \\
\text { Stripping and shaping } \\
\text { hemi-ogivale shape }\end{array}$ \\
\hline 2 Mrimming and finishing restorations \\
\hline lance shaped blade
\end{tabular}

Figure 16: Sonic abrasive tips.

Air abrasion [34]:

Air abrasion eradicates the needless destruction of sound tooth structure associated with traditional restorative techniques while leaving the tooth ideally conditioned for the beneficial caries-inhibiting and strengthening properties of bonded restorations.

\section{FACE (Fluorescence-aided caries excavation) [35]:}

With fluorescence aided caries excavation areas exhibiting orange-red fluorescence can be selectively removed with the bur. It is more effective in removing infected dentin reducing loss of healthy tooth structure.

\section{Lasers for pediatric patients [36]:}

Children are the first in line to receive dental laser treatment and based on the micro dentistry painless drilling. Laser-supported dental diagnosis and treatment is key for treating children successfully according to the modern research in paediatric dentistry [41].

\section{Ozone [37]:}

Its ability to arrest and reverse carious lesions in a predictable way opened up a new chapter in minimal intervention dentistry. Moreover, its efficacy in decreasing resistant poly microbial root canal flora seems very promising. 


\begin{tabular}{|c|c|c|c|c|}
\hline $\begin{array}{c}\text { Caries Severity } \\
\text { Index }\end{array}$ & $\begin{array}{l}\text { Diagnodent } \\
\text { Reading }\end{array}$ & $\begin{array}{c}\text { Clinical } \\
\text { diagnosis }\end{array}$ & $\begin{array}{l}\text { Radiographic } \\
\text { interpretation }\end{array}$ & Treatment plan \\
\hline 1 & $<10$ & $\begin{array}{l}\text { May be a } \\
\text { sound tooth }\end{array}$ & Normal & $\begin{array}{l}10 \mathrm{Sec} \mathrm{O}_{3} / \mathrm{Seal} \text { Fissures if } \\
\text { indicated with GIC or } \\
\text { flowable composite }\end{array}$ \\
\hline 2 & $10-16$ & $\begin{array}{l}\text { White spot } \\
\text { lesions }\end{array}$ & $\begin{array}{l}\text { Normal (lesion } \\
\text { not seen on } \mathrm{x} \text { - } \\
\text { rays) }\end{array}$ & $\begin{array}{c}40 \sec \mathrm{O} 3 \text { and } \\
\text { remineralisation therapy } \\
\text { Air abrasion and/or seal } \\
\text { fissures }\end{array}$ \\
\hline 3 & $20-24$ & $\begin{array}{c}\text { Carious lesion } \\
\text { at EDJ }\end{array}$ & $\begin{array}{c}\text { May not be visible } \\
\text { on } x \text {-rays }\end{array}$ & $\begin{array}{c}\text { Air abrasion/etch/40 } \mathrm{sec} \mathrm{O}_{3} \\
\text { therapy and restoration with } \\
\mathrm{GIC} / \text { composite }\end{array}$ \\
\hline 4 & $25-29$ & $\begin{array}{c}\text { Caries } \\
\text { involving } \\
1-2 \mathrm{~mm} \\
\text { of dentin }\end{array}$ & $\begin{array}{l}\text { May/may not } \\
\text { be visible on } \mathrm{X}- \\
\text { rays }\end{array}$ & $\begin{array}{l}\text { Remove infected dentin, leave } \\
\text { affected dentin. Etching - } 60 \\
\sec \mathrm{O}_{3} \text { therapy and restore } \\
\text { with GIC/composite/Light } \\
\text { cure } \\
\text { GIC }\end{array}$ \\
\hline 5 & $>30$ & $\begin{array}{c}\text { Caries } \\
\text { involving } \\
2 \mathrm{~mm} \text { of dentin }\end{array}$ & $\begin{array}{l}\text { Mostly visible } \\
\text { on X-Rays }\end{array}$ & $\begin{array}{l}\text { Remove infected dentin to } \\
\text { leave affected dentin, ozone } \\
\text { exposure for } 60 \mathrm{sec} . \\
\text { depending on remaining } \\
\text { dentin thickness liner/base } \\
\text { and restoration. }\end{array}$ \\
\hline 6 & $>99$ & $\begin{array}{l}\text { Deep carious } \\
\quad \text { lesion, } \\
\text { may/may not } \\
\text { involve pulp. }\end{array}$ & $\begin{array}{l}\text { Visible on } x \text {-rays } \\
\text { and assessing } \\
\text { pulp vitality }\end{array}$ & $\begin{array}{l}\text { If vital, indirect pulp capping } \\
\text { is advised. Expose Os for } 120 \\
\text { sec and seal with GIC. After } 1 \\
\text { month, reassess and If } \\
\text { remineralisation is evident, it } \\
\text { can be restored with a } \\
\text { permanent restoration. }\end{array}$ \\
\hline
\end{tabular}

Figure 17: Clinical applications of ozone.

\section{Restorative therapy}

Pit and fissure sealants and preventive resin restoration [38]:

The idea of prophylactic fissure sealants or preventive resin restoration was first reported by Simonsen and Stallard (1977). Preventive resin restoration utilizes the non - invasive treatment modalities for borderline or questionable caries. It is a natural extension of the use of occlusal sealants. It integrates the preventive approach of the sealant therapy for caries - susceptible pits and fissures with the therapeutic restoration of incipient caries with composite resin.

Age ranges for extended sealant application:

A high percentage of occlusal lesions occurred in the first 3 years after eruption.

- 3-4 years of age for the primary molar sealant application

- 6-7 years of age for the permanent first molar

- 11-13 years of age for the permanent second molar.
Bioactive and biomimetic materials [39]:

A bioactive material is one that forms a surface layer of an appetite-like material in the presence of an inorganic phosphate solution. The calcium silicate- and calcium aluminate-based cements a wide range of calcium-based or calcium-containing materials that demonstrated bioactivity.

Sustained release materials, responsive release and smart materials [40]:

Smart materials are materials that have properties which can be altered in a controlled fashion by stimuli like stress, temperature, moisture, $\mathrm{pH}$ and electric or magnetic fields.

\section{Smart composites}

Aaron S. Posner first described AMORPHOUS CALCIUM PHOSPHATE (ACP) in 1960s. ACP has been evaluated as a filler phase in bioactive polymeric composites. In addition to excellent biocompatibility, the ACP containing composites release calcium and phosphate ions into saliva. When the $\mathrm{pH}$ level in the mouth drops below 5.8, these ions merge within seconds to form a gel.

\section{Self-healing composites}

One of the first self-repairing or self-healing synthetic materials reported is resin-based epoxy system which contained resin filled microcapsules. If a crack occurs in the epoxy composite material, some of the microcapsules are destroyed near the crack and release the resin. The resin subsequently fills the crack and reacts with a Grubbs catalyst dispersed in the epoxy composite, resulting in a polymerization of the resin and a repair of the crack.

\section{Silver nanoparticles in dental biomaterials [41]:}

Several studies have shown that nanoparticulate form of sliver possesses an inhibitory effect against many bacteria and fungi, including S. mutans, C. albicans, P. aeruginosa, E. faecalis, and S. aureus, among others, which decreases the occurrence of secondary caries.

Biomaterials in caries prevention and treatment [42]:

- $\quad$ Recently, some novel biomaterials have been developed in caries prevention and treatment.

- Nanoparticles of amorphous calcium phosphate (NACP) and $\mathrm{CaF} 2$ 
- $\quad$ PAMAM - 9 Poly (Amido Amine)

- $\quad$ Quaternary ammonium methacrylate (QAMs).

\section{Adhesive restorations}

- $\quad$ Bonded amalgam restorations (Amalgam bond)

- $\quad$ Novel adhesive systems

- $\quad$ Compomers and giomers.

\section{Resin infiltration [43]:}

Resin infiltration is an advanced way of treating initial carious lesions that fits perfectly with minimal intervention dentistry. Infiltration of non-cavitated lesions of proximal and smooth surfaces of deciduous and permanent teeth is a non-invasive method of preserving tooth structure.

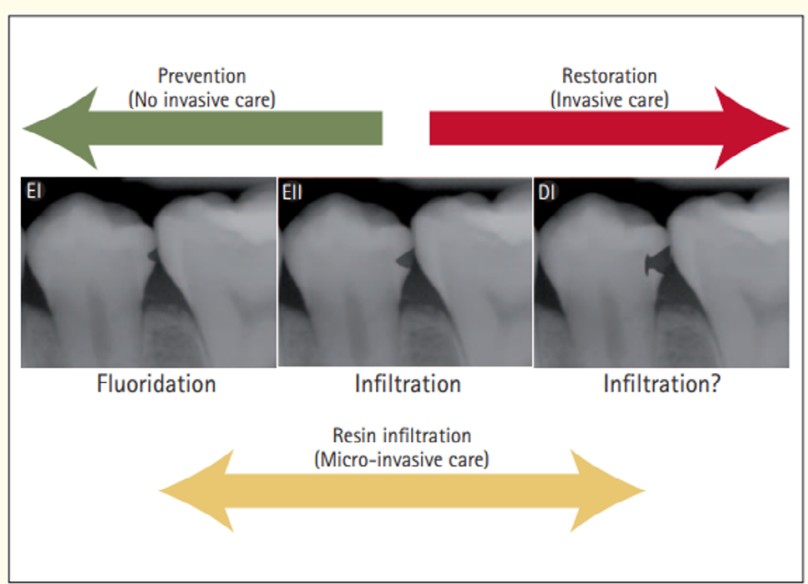

Figure 18: Resin infiltration and Minimal Intervention Dentistry.
Nanotechnology in paediatric dentistry [44]:

Nano dentistry will make possible the maintenance of comprehensive oral health care by employing nanomaterials, biotechnology, including tissue engineering and dental nanorobotics.

Fluoridated HA coated preformed metal crowns [45]:

Clark., et al. in 2013 developed a novel technology to manufacture Fluoridated HA crystals directly on preformed metal crowns so as to provide full coverage restorations with anti-cariogenicity benefiting caries susceptible paediatric and adult patients.

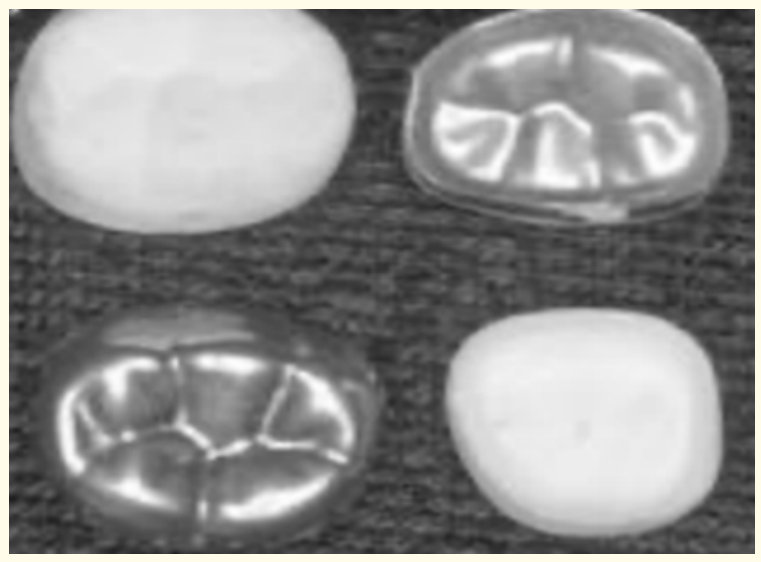

Figure 19: Fluoridated HA coated Preformed Metal crowns.

Tailor made dental recalls

AAPD Recall Guidelines [46]:

\begin{tabular}{|c|c|c|c|c|c|}
\hline \multirow[b]{2}{*}{ Risk Category } & \multirow[b]{2}{*}{ Diagnostics } & \multicolumn{3}{|c|}{ Interventions } & \multirow[b]{2}{*}{ Restorative } \\
\hline & & Fluoride & $\begin{array}{c}\text { Dietary } \\
\text { Counseling }\end{array}$ & Sealants & \\
\hline Low risk & $\begin{array}{l}\text { - Recall every six to } 12 \\
\text { months } \\
\text { - Radiographs every } 12 \\
\text { to } 24 \text { months }\end{array}$ & $\begin{array}{l}\text { - Drink optimally fluoridated } \\
\text { water } \\
\text { - Twice daily brushing with } \\
\text { fluoridated toothpaste }\end{array}$ & Yes & Yes & -Surveillance \\
\hline Moderate risk & $\begin{array}{l}\text { - Recall every six months } \\
\text { - Radiographs every six } \\
\text { to } 12 \text { months }\end{array}$ & $\begin{array}{l}\text { - Drink optimally fluoridated } \\
\text { water } \\
\text { - Twice daily brushing with } \\
\text { fluoridared toorhpaste } \\
\text { - Fluoridc supplerments } \\
\text { - Professional topical treatment } \\
\text { every six months }\end{array}$ & Yes & Yes & $\begin{array}{l}\text { - Active surveillance of non- } \\
\text { cavitated (white spot) } \\
\text { carics losions } \\
\text { - Restore of cavitated or } \\
\text { enlarging caries lesions }\end{array}$ \\
\hline High risk & $\begin{array}{l}\text { - Recall cvcry threc months } \\
\text { - Radiographs every six } \\
\text { months }\end{array}$ & $\begin{array}{l}\text { - Drink optimally fluoridatcd } \\
\text { water } \\
\text { - Brushing with } 0.5 \text { percent } \\
\text { fluoride gel/paste } \\
\text { - Fluoride supplements } \\
\text { - Professional topical treatment } \\
\text { every three months } \\
\text { - Silver diamine fluoride on } \\
\text { cavitated lesions }\end{array}$ & Yes & Ycs & $\begin{array}{l}- \text { Activc surveillance of non- } \\
\text { cavitated (white spot) } \\
\text { caries lesions } \\
\text { - Restorc of cavitated or } \\
\text { enlarging caries lesions }\end{array}$ \\
\hline
\end{tabular}

Figure 20: AAPD Recall Guidelines. 
Dental recall (NICE guideline) [47]:

For practical reasons, patients should be assigned (at a particular point in time) a recall interval of $3,6,9$ or 12 months if they are below 18 years of age, or $3,6,9,12,15,18,21$ or 24 months if they are 18 years or over.

\section{Conclusion}

Now paediatric dentistry has a better understanding of prevention of dental diseases, with the advent of advanced restorative materials but still there is reluctance in a wide group of dentists to use these materials and techniques. The reasons can be cost of the equipment and the consumable materials which becomes a deciding factor for most practitioners. The future of remineralisation dentistry lies in the development of remineralising agents that have the capability to remineralise dentinal lesions as well as smart biomimetic materials to restore the lost tooth structure. As paediatric dentists practicing MIPD not only makes the treatment efficient but also makes behaviour management of the child much easier due to advance painless microinvasive and non-invasive techniques.

\section{Bibliography}

1. Featherstone John DB. "Caries prevention and reversal based on the caries balance". Pediatric Dentistry 28.2 (2006): 128132.

2. Martin J Tyas. "Minimal intervention dentistry-a review FDI Commission Project”. International Dental Journal 50 (2002): 1-97.

3. Brostek AM and Walsh LJ. "Minimal Intervention Dentistry in General Practice". Journal of Oral Health and Dental Management 13.2 (2014).

4. Innes NP and Manton DJ. "Minimum intervention children's dentistry-the starting point for a lifetime of oral health". British Dental Journal 223.3 (2017): 205-213.

5. Guerrieri A., et al. "Minimal intervention dentistry: part 4. Detection and diagnosis of initial caries lesions". British Dental Journal 213 (2012): 551-557.

6. Forgie AH., et al. "The assessment of an intra-oral video camera as an aid to occlusal caries detection". International Dental Journal 53.1 (2003): 3-6.

7. Manton DJ. "Diagnosis of the early carious lesion". Australian Dental Journal 58.1 (2013): 35-39.
8. Mattos-Silveira., et al. "Does the ball-ended probe cause less damage than sharp explorers? -An ultrastructural analysis". BMC Oral Health 16 (2016): 39.

9. Pitts NB and Ekstrand KR. "ICDAS Foundation. International Caries Detection and Assessment System (ICDAS) and its International Caries Classification and Management System (ICCMS)-methods for staging of the caries process and enabling dentists to manage caries". Community Dentistry and Oral Epidemiology 41.1 (2013): 41-52.

10. Sitbon Y., et al. "Minimal intervention dentistry II: part 1. Contribution of the operating microscope to dentistry". British Dental Journal 216.3 (2014): 125-130.

11. S Twetman., et al. "Risk assessment - can we achieve consensus?" Community Dentistry and Oral Epidemiology 41.1 (2013): e64-e70.

12. Srilatha A., et al. "Advanced diagnostic aids in dental caries - A Review". Journal of Global Oral Health 2.2 (2019): 118-127.

13. Nemmarugommula N., et al. "Caries Activity Tests". RRJDS 1.3 (2013): 50-59.

14. Ilango P., et al. "Chlorhexidine-A Miracle Chemical". International Journal of Current Research and Review 5.18 (2013): 26-34.

15. Moon-JinJeong. "Comparing Chewable and Manual Toothbrushes for Reducing Dental Plaque A Pilot Study". Journal of Dental Hygiene Science 17.3 (2017): 267-274.

16. Bretz WA and Rosa OP. "Emerging technologies for the prevention of dental caries. Are current methods of prevention sufficient for the high-risk patient?" International Dental Journal 61.1 (2011): 29-33.

17. Nebu Philip. "Ecological Approaches to Dental Caries Prevention: Paradigm Shift or Shibboleth?" Caries Research 52 (2018): 153-165.

18. Guo L and Edlund A. "Targeted Antimicrobial Peptides: A Novel Technology to Eradicate Harmful Streptococcus Mutans". Journal of the California Dental Association 45.10 (2017): 557-564.

19. Ramos-Gomez FJ., et al. "Minimal intervention dentistry: part 3. Paediatric dental care-prevention and management protocols using caries risk assessment for infants and young children". British Dental Journal 213.10 (2012): 501-508. 
20. Gao., et al. "Caries remineralisation and arresting effect in children by professionally applied fluoride treatment-a systematic review". BMC Oral Health 16 (2016): 12.

21. Horst JA., et al. "UCSF Protocol for Caries Arrest Using Silver Diamine Fluoride: Rationale, Indications, and Consent". Journal of the California Dental Association 44.1 (2016): 16-28.

22. Batra A and Shetty V. "Non-fluoridated remineralising agentsa review of literature". Journal of Evolution of Medical and Dental Sciences 10.9 (2021): 638-644.

23. Blum IA., et al. "Factors influencing repair of dental restorations with resin composite". Clinical, Cosmetic and Investigational Dentistry (2014): 6.

24. Frencken JE. "Atraumatic restorative treatment and minimal intervention dentistry". British Dental Journal 223.3 (2017): 183-189.

25. Altoukhi DH., et al. "Hall technique for carious primary molars: a review of the literature". Dentistry Journal 8.1 (2020): 11.

26. Reddy VK., et al. "Bromelain vs Papain Gel for Caries Removal in Primary Teeth". The Journal of Contemporary Dental Practice 20.11 (2019): 1345-1349.

27. Schwendicke and Frencken. "Managing Carious Lesions: Consensus Recommendations on Carious Tissue Removal". Advances in Dental Research 28.2 (2016): 58-67.

28. Holmgren CJ., et al. "Minimal intervention dentistry: part 5. Atraumatic restorative treatment (ART)-a minimum intervention and minimally invasive approach for the management of dental caries". British Dental Journal 214.1 (2013): 11-18.

29. A Banerjee. "Minimal intervention dentistry: part 7. Minimally invasive operative caries management: rationale and techniques". British Dental Journal 214.3 (2013).

30. Dammascke T., et al. "Efficiency of the polymer bur SmartPrep compared with conventional tungsten carbide bud bur in dentin caries excavation". Operative Dentistry 31 (2006): 256-260.

31. Martin J Tyas. "Minimal intervention dentistry-a review FDI Commission Project". International Dental Journal 50 (2000): $1-12$.

32. KJM S öderholm., et al. "Determinants of Quality in Operative Dentistry". Critical Review of Oral Biology and Medicine 9 (1998): 464.
33. Decup F and Lasfargues JJ. "Minimal intervention dentistry II: part 4. Minimal intervention techniques of preparation and adhesive restorations. The contribution of the sono-abrasive techniques". British Dental Journal 216.7 (2014): 393.

34. Rainey JT. "Air abrasion: an emerging standard of care in conservative operative dentistry". Dental Clinics of North America 46 (2002): 185-209.

35. Lennon AM., et al. "Fluorescence-aided caries excavation (FACE), caries detector, and conventional caries excavation in primary teeth". Pediatric dentistry 31.4 (2009): 316-319.

36. Hegde VS and Khatavkar RA. "A new dimension to conservative dentistry: Air abrasion". Journal of Conservative Dentistry $13.1(2010)$.

37. Reddy SA., et al. "Role of Ozone Therapy in Minimal Intervention Dentistry and Endodontics-A Review". Journal of International Oral Health 5.3 (2013): 102-108.

38. Frencken JE., et al. "Minimal intervention dentistry for managing dental caries-a review: report of a FDI task group". International Dental Journal 62.5 (2012): 223-243.

39. Jefferies SR. "Bioactive and Biomimetic Restorative Materials: A Comprehensive Review. Part I". Journal of Esthetic and Conservative Dentistry 26.1 (2014): 14-26.

40. Corrêa JM., et al. "Silver nanoparticles in dental biomaterials". International Journal of Biomaterials (2015): 2015.

41. Cheng L., et al. "Biomaterials in Caries Prevention and Treatment". Interface Oral Health Science 2017 (2016): 101-110.

42. Tyas MJ and Burrow MF. "Adhesive restorative materials: a review". Australian Dental Journal 49.3 (2004): 112-121.

43. Nivashini GSV. "Resin infiltration technique - A review". International Journal of Current Research 9.04 (2021): 4926749269.

44. Kanaparthy R and Kanaparthy A. "The changing face of dentistry: nanotechnology". International Journal of Nanomedicine 6 (2011): 2799-2804.

45. Clark DR., et al. "In vitro an - caries effect of fluoridated hydroxyapa_te coated preformed metal crowns". European Archives of Paediatric Dentistry 14.4 (2013): 253-258.

Citation: Voleti Sri Srujana Aravinda., et al. "Minimal Extension for Maximal Results - Review on Minimal Intervention Paediatric Dentistry". Acta Scientific Dental Sciences 6.1 (2022): 102-114. 
46. Caries-risk Assessment and Management for Infants, Children, and Adolescents Latest Revision 2021". The Reference Manual of Pediatric Dentistry (2021).

47. National Institute for Clinical Excellence (NICE). "Dental recall: Recall interval between routine dental examinations". Clinical guideline 19. London (2004).

\section{Assets from publication with us}

- Prompt Acknowledgement after receiving the article

- Thorough Double blinded peer review

- Rapid Publication

- Issue of Publication Certificate

- High visibility of your Published work

Website: www.actascientific.com/

Submit Article: www.actascientific.com/submission.php

Email us: editor@actascientific.com

Contact us: +919182824667 